\title{
Proses Belajar Efektif dalam Membentuk Kecerdasan Intelektual dan Motivasi Belajar pada Mahasiswa Mahad Ali bin Abi Thalib Yogyakarta
}

\author{
Syaiful Amry \\ Magister Studi Islam Program Pascasarjana Universitas Muhammadiyah Yogyakarta (UMY) \\ syaifulamry95@gmail.com
}

\begin{abstract}
Abstrak
Penelitian ini berjudul proses belajar efektif dalam membentuk kecerdasan intelektual dan motivasi belajar pada mahasiswa di Mahad Ali bin Abi Thalib Yogyakarta. Adapun tujuan penelitian ini adalah menjelaskan bagaimana proses belajar efektif mahasiswa, mengetahui kecerdasan intelektual mahasiswa, memahami motivasi belajar mahasiswa, serta adakah pengaruhnya antara proses belajar efektif dengan kecerdasan intelektual dan motivasi belajar pada mahasiswa di Mahad Ali bin Abi Thalib Yogyakarta.

Jenis dan pendekatan penelitian ini adalah penelitian lapangan dengan pendekatan kualitatif (deskriptif). Adapun subjek penelitian adalah enam (6) mahasiswa. Metode pengumpulan data dengan wawancara, observasi, dan dokumentasi. Teknik analisis data dengan cara reduksi, penyajian, penarikan, kredibilitas data.

Hasil dari pada penelitian ini menunjukkan bahwa: 1) proses belajar efektifmahasiswa adalah dalam kegiatan pembelajarannya bahwa aspek presensi dan mengerjakan tugas dinilai baik, di lihat dari berdiskusi dan menanyakan kepada teman untuk mengulang materi maupun belajar bersama. Wadah dan organisasi belajar menggunakan kurikulum Silsilah Lughotul Arabiyyah. Serta para guru sudah memberikan motivasi belajar dan membantu dalam pemahaman materi. Kemudian faktor pendukung datang dari diri sendiri karena minat dalam belajar bahasa Arab. 2) kecerdasan intelektual mahasiswa diperoleh dengan mengulang kembali materi pelajaran, mendengarkan penjelasan guru, dan bertanya kepada teman dan guru. 3) motivasi belajar mahasiswa adalah adanya dorongan dalam diri mempelajari bahasa Arab dan studi Islam, bisa berbahasa Arab aktifmaupun pasif, serta karena bahasa Arab adalah ilmu untuk mempelajari al-qur'an. 4) selanjutnya pengaruh proses belajar efektif dilihat dari pada mahasiswa sendiri, apakah dia lulusan dari pondok ataukah sudah pernah mempelajari bahasa arab sebelumnya. Karena kendala yang sering didapat oleh mahasiswa adalah penguasaan bahasa Arab secara mendasar.
\end{abstract}

Kata kunci: Proses belajar, motivasi belajar, kecerdasan intelektual

\begin{abstract}
The Effective Learning Processes in Shaping Intellectual Intelligence and Learning Motivation in Students at Ma'had Ali Bin Abi Thalib Yogyakarta

This study entitled the effective learning process in shaping intellectual intelligence and learning motivation in students at Ma'had Ali Bin Abi Thalib Yogyakarta. The purpose of this study is to explain how the student's effective learning process, knowing students' intellectual intelligence and understanding students' motivation. In addition, the purpose is to investigate whether there is any influence between the effective learning process with intellectual intelligence and learning motivation on students at Ma'had Ali bin Abi Thalib Yogyakarta.
\end{abstract}


The type and approach of this research is field research with a qualitative (descriptive) approach. The research subjects were six (6) students. Data collection was done by the methods of interview, observation, and documentation. Data analysis techniques were done using reduction, presentation, withdrawal, and data credibility.

The results of this study indicate that: 1) the effective learning process of students is that, in their learning activities, the aspect of attendance and work on assignments is categorized to be good. It is seen from the discussions, asking friends to repeat the material, and studying together. The place and learning organizations use The Genealogy of Lughah al-Arabiyah curriculum. The teachers also have motivated to learn and assist in understanding the material. Then the supporting factor comes from themselves because of their interest in learning Arabic. 2) Students' intellectual intelligence is obtained by repeating the subject matter, listening to the teacher's explanation, and asking friends and teachers. 3) Students'learning motivation is the encouragement in learning Arabic and Islamic studies, the ability to speak active or passive Arabic, and the fact that Arabic is the science of learning the Qur'an. 4) Then the effect of the effective learning process can be seen from the students themselves, whether they were graduated from the Islamic boarding house or have studied Arabic before. It is because the obstacle that is often in students is the basic mastery of Arabic.

Keywords: effective learning process, intellectual intelligence, learning motivation.

\section{PENDAHULUAN}

Pendidikan dalam hakikatnya adalah proses belajar dengan pemberian nilai dari seorang pengajar berupa nilai pengetahuan, keterampilan maupun teknologi. Sehingga dalam arti luas bisa dikatakan seluruh aspek hidup interaksi individu dengan lingkungan sekitar di lihat dari formal, informal, dan informal. ${ }^{1}$ Suatu pendidikan yang bagus memiliki tujuan untuk diri sendiri dengan cakupan yang luas sampai ketaraf tertentu.

Efektivitas proses pembelajaran secara konseptual dapat diartikan sebagai perlakuan dalam proses pembelajaran yang memiliki ciri-ciri : a) suasana yang dapat berpengaruh, atau hal yang berkesan terhadap penampilan; dan b) keberhasilan usaha atau tindakan yang berpengaruh terhadap hasil belajar siswa.

Pendidikan dalam bidang pertumbuhan akal (intelektual) pendidikan dapat menolong individu untuk meningkatkan, mengembangkan dan menumbuhkan kesediaan, bakat-bakat, minat, dan kemampuan akalnya dan memberinya pengetahuan dan keterampilan akal yang perlu

'Makmun, A.S. 2004." Psikologi kependidikan". Bandung: Rosdakarya. h. 55. dalam hidupnya. Kecerdasan intelektual adalah suatu bentuk penafsiran kemampuan kognitif seseorang, yang berasaskan pada kemampuan bertindak dengan menetapkan suatu tujuan, untuk berfikir secara rasional maupun untuk berhubungan dengan lingkungan sekitarnya yang memuaskan.

Tujuan dari proses pendidikan adalah menyangkut kepentingan peserta didik atau pribadi, masyarakat dan lapangan pekerjaan. Proses pendidikan yang terarah kepada peningkatan penguasaan pengetahuan, kemampuan, keterampilan, pengembangan sikap dan nilai-nilai dalam rangka pembentukan dan pengembangan peserta didik. ${ }^{2}$

Faktor permasalahan yang sering terjadi dikalangan mahasiswa adalah diantaranya kurang manajemen waktu bagaimana mengelola waktu dan jadwal belajar di kampus, minat terhadap matakuliah, cara penyampaian materi dari dosen, dan lain sebagainya. Karena dari faktor tersebut pasti ada dampak negatif untuk mahasiswa sendiri.

${ }^{2}$ Sukmadinata, Nana Syaodih. 2003. "Landasan Psikologi Proses Pendidikan". Bandung: PT Remaja Rosdakarya, h.4. 
Seperti pada kenyataanya peneliti jumpai banyak dari mahasiswa yang belajar daya tahan dan konsentrasi dalam mengikuti kegiatan belajar sedikit terganggu. Mulai dari mengantuk dikelas dan sering izin untuk waktu yang tidak ditentukan, semua itu akan berdampak kepada hasil belajar ke tingkat selanjutnya. Mahasiswa di Mahad Ali sebagai tempat penelitian banyak keunikan tersendiri. Para mahasiswa dari kalangan umur dan latar belakang yang berbeda pula. Ada yang bekerja sambil kuliah, ada yang sudah berumur dan berkeluarga. Waktu belajar di Mahad Ali khusus untuk laki-laki pada waktu siang hari antara sehabis dhuhur sampai sore sekitar jam 5 lebih. ${ }^{3}$ Waktu belajar inilah yang membuat sebagian mahasiswa jarang hadir maupun antusias dalam mengikuti proses belajar dikelas.

Banyak kritik yang ditujukan pada cara guru mengajar yang terlalu menekankan pada penguasaan sejumlah informasi/konsep belaka. Tidak dapat disangkal bahwa konsep merupakan suatu hal yang sangat penting, namun bukan terletak pada konsep sendiri. Melainkan terletak bagaimana konsep tersebut dipahami oleh subjek didik. Pentingnya pemahaman konsep dalam proses belajar mengajar sangat memengaruhi sikap, keputusan, dan caracara memecahkan masalah. ${ }^{4}$ Dalam kondisi demikian faktor kompetensi guru harus mampu meramu wawasan pembelajaran yang lebih menarik dan disukai oleh peserta didik.

Rumusan masalah penelitian ini adalah bagaimana belajar efektif, kecerdasan intelektual serta motivasi belajar yang ada di Mahad Ali bin Abi Thalib Yogyakarta. Kemudian tujuan penelitian untuk menjelaskan belajar efektif, kecerdasan intelektual dan motivasi belajar serta adakah pengaruh antara proses belaajr efektif dengan kecerdasan intelektual dan motivasi belajar di Mahad Ali bin Abi Thalib Yogyakarta.

Proses belajar efektif adalah tujuan dalam pembelajaran selama kegiatan proses

${ }^{3}$ Hasil obervasi pada hari Senin, 9 Desember 2019 jam 13.00 .

${ }^{4}$ Trianto. 2009. "Mendesain Model Pembelajaran Inovatif-Progresif', Jakarta: Kencana, h.6. belajar yang mencakup seluruh sasaran dan ukuran sehingga dapat menghasilkan kegiatan pembelajaran yang di harapkan. Efektivitas proses belajar adalah ukuran keberhasilan dari suatu proses interaksi antara guru dan peserta didik dalam suasana edukatif sehingga mencapai tujuan pembelajaran. ${ }^{5}$

Kecerdasan intelektual adalah suatu kemampuan berpikir secara rasional dan terarah sesuai tindakan kognitif yang komplek serta intelegensi pada hakikatnya merupakan suatu kemampuan dasar yang bersifat umum untuk memperoleh suatu kecakapan yang mengandung berbagai komponen.

Motivasi belajar adalah kehendak dari dalam diri seseorang yang memunculkan perasaan dan reaksi kemudian muncul dorongan untuk melakukan aktivitas dan tujuan yang akan dicapai dalam pembelajaran.

\section{METODE PENELITIAN}

Jenis penelitian ini merupakan penelitian lapangan (field research) dengan pendekatan kualitatif deskriptif. Penelitian dengan pendekatan kualitatif menurut Sukmadinata adalah suatu penelitian yang ditujukan untuk mendeskripsikan dan menganalisis fenomena, peristiwa, aktivitas sosial, sikap, kepercayaan, persepsi, pemikiran orang secara individual maupun kelompok. ${ }^{6}$ Pendekatan kualitatif adalah pendekatan yang dilakukan untuk memahami fenomena tentang apa yang dialami subjek penelitian secara holistik dan data yang diperoleh dideskripsikan dalam bentuk katakata. $^{7}$

Subjek dalam penelitian ini adalah mahasiswa. Peneliti memilih 6 Mahasiswa dari 25 orang dalam (1) satu kelas pada tingkatan kedua (2) di Ma'had Ali bin Abi

${ }^{5}$ Rohmawati, Afifatu. 2015. "Efektivitas Pembelajaran". Jurnal Pendidikan Usia Dini. Vol. 9 Edisi 1, April 2015 h.19

${ }^{6}$ Syaodih Sukmadinata, Nana. 2014. "Metode Penelitian Pendidikan". Bandung: PT Remaja Rosdakarya. h. 60.

${ }^{7}$ Moleong, Lexy. 2014."Metodologi Penelitian Kualitatif'. Bandung: Remaja Rosdakarya. h. 6. 
Thalib Yogyakarta dengan berbagai kriteria. Di antaranya adalah yang sudah berkeluarga, fokus belajar di Mahad Ali, serta bekerja dan kuliah selain belajar di Mahad Ali. Masingmasing dari kriteria tersebut di pilih 2 (dua) mahasiswa sebagai penelitian. Peneliti memilih mahasiswa sebagai subjek penelitian karena subjek penelitian yang mengalami secara langsung masalah penelitian, kemudian memudahkan peneliti untuk memperoleh data secara mendalam. Peneliti memilih 6 subjek tersebut karena sesuai kriteria yang sesuai.

Operasional konsep pada penelitian ini adalah:

Proses belajar efektif; presentasi waktu belajar, perilaku melakukan tugas, mengutamakan kemampuan siswa, dan suasana belajar yang positif. ${ }^{8}$ Selanjutnya faktor job description guru dalam proses belajar; perencanaan instruksional, organisasi belajar, menggerakkan usaha, dan supervisi atau pengawasan. ${ }^{9}$ Kemudian faktor yang mempengaruhi proses belajar; faktor individu, faktor lingkungan, dan faktor pendekatan belajar. ${ }^{10}$

Kecerdasan intelektual; baik ingatan, mudah menarik kesimpulan, cepat dalam mengamati, dan cakap memecahkan masalah. ${ }^{11}$

Motivasi belajar; adanya dorongan dan kebutuhan dalam belajar, adanya hasrat dan keinginan berhasil, adanya harapan dan cita-cita di masa depan, serta adanya jiwa penghargaan dalam belajar. ${ }^{12}$

Tenik pengumpulan data dalam penelitian ini dengan wawancara (interview), Selanjutnya peneliti menggunakan pedoman dari pada kerangka teori yang selanjutnya dijadikan

\footnotetext{
${ }^{8}$ Trianto. 2009. "Mendesain Model ..,h.20

${ }^{9}$ Ahmadi, Abu dan Joko Prasetya. 1997. "Strategi Belajar Mengajar". Bandung: Pustaka Setia, h.33

${ }^{10}$ Kurniawan, Deni. 2014. "Pembelajaran Terpadu Tematik (Teori, Praktik, dan Penilaian)'”. Bandung: Alfabeta, h. 22.

${ }^{11}$ Mujib, A., dan Mudzakir, Y. 2000. "Nuansa Nuansa Psikologi Islami”. Raja Grafindo Persada. Jakarta, h. 42

${ }^{12}$ Uno, Hamzah B. 2007. “Teori Motivasi dan Pengukurannya”. Jakarta: Bumi Aksara. h.. 23
}

sebagai bahan pembuatan (insturmen penelitian) pertanyaan wawancara. Kemudian observasi, Observasi yang peneliti lakukan adalah dengan bertanya kepada pegawai di Mahad Ali untuk memperoleh data pendukung, seperti buku panduan mahasiswa sebagai bahasan hasil penelitian. Peneliti melihat langsung proses belajar yang dilakukan oleh guru di dalam kelas, supaya memperoleh gambaran dalam penelitian. Selanjutnya dokumentasi, metode ini digunakan peneliti untuk lebih mengetahui suatu subjek yang akan peneliti lakukan penelitian lebih lanjut.

Teknik analisis data dapat dilakukan supaya data yang terkumpul dapat di olah dan di telaah secara kritis. Dari hasil metode pengumpulan data seperti observasi, wawancara dan dokumentasi. Peneliti mengungkapkan bahwa dalam tahap analisis data ini berdasarkan pendapat Mile's dan Huberman dalam empat kategori ${ }^{13}$, yaitu reduksi data, display data penarikan kesimpulan, dan kredibilitas data. Penelitian di lakukan mulai dari tanggal 2 februari sampai dengan 10 februari 2020. Peneliti melakukan triangulasi data dari sebelum melakukan riset, yaitu pada saat observasi, di sini peneliti menanyakan kepada pegawai pada bagian Tata Usaha (TU). Peneliti menetapkan jumlah subjek informan yang akan di wawancara, langkah-langkah selanjutnya adalah dengan mendeskripsikan ungkapan atau pendapat yang sudah didapatkan melalui wawancara. Setelah mendapatkan data melalui wawancara, peneliti memilah atau mereduksi guna mendapatkan pernyataan yang layak untuk di sajikan, berikutnya data tersebut di tarik kesimpulan untuk memperoleh data akhir yang valid.

\section{HASIL DAN PEMBAHASAN}

Proses belajar efektif pada Mahasiswa di Mahad Ali bin Abi Thalib disini mencakup dengan aspek mata pelajaran, waktu belajar,

\footnotetext{
${ }^{13}$ Mathew B. Miles dan Michael A. Huberman. 1992."Analisis Data Kualitatif". Terj. Rohendi Rohidi. Jakarta: UI Press. H. 16-17.
} 
komunikasi antar guru dan mahasiswa. Menurut indikatornya terbagi menjadi presensi waktu belajar, perilaku saat melaksanakan tugas, kemampuan siswa, suasana belajar, perencanaan instruksional, organisasi belajar, membangkitkan motivasi, supervisi guru, penilaian evaluasi. Serta ada 3 faktor yang memperngaruhi proses belajar yaitu faktor belajar individu, faktor dari lingkungan dan faktor strategi dan metode.

\section{Presensi waktu belajar}

Untuk presensi atau absen pada setiap waktu belajar rata-rata mahasiswa hadir secara rutin. Di setiap mata kuliah sudah memenuhi kriteria untuk hadir di kelas secara rutin.

\section{Perilaku melaksanakan tugas}

Para mahasiswa di mahad Ali sering mengerjakan tugas harian dengan bantuan teman, meskipun ada yang mengerjakan sendiri. Tapi mengerjakan dengan bantuan teman akan lebih dapat dicerna dan dimengerti bersamasama.

\section{Kemampuan siswa}

Kemampuan mahasiswa mahad Ali dalam mempelajari atau melatih diri adalah dengan cara mengulang materi pelajaran yang telah disampaikan sebelumnya, dan juga dengan latihan soal maupun mengerjakan tugas atau PR (pekerjaan rumah).

\section{Suasana belajar}

Cara agar para mahasiswa menciptakan suasana belajar yang akrab dan positif adalah dengan banyak ngobrol, sharing pendapat untuk mempermudah materi pelajaran yang dipelajari dikelas.

\section{Perencanaan instruksional}

Guru maupun ustadz yang mengajar hanya memakai media spidol dan papan tulis, karena kurikulum yang di ajarkan keseluruhan adalah bahasa arab. Hal tersebut cukup mendukung untuk proses belajar mengajar di Mahad Ali.

\section{Organisasi belajar}

Organisasi belajar di sini dapat dikatakan alat untuk mendukung dalam proses belajar, yaitu buku maupun kurikulum yang berlaku di mahad. Hasil dari wawancara mengatakan sudah mencukupi dalam hal metode pembelajaran, meskipun buku yang di gunakan yaitu Silsilah Lughotul Arabiyyah.

\section{Membangkitkan motivasi}

Guru di mahad Ali hanya beberapa saja yang memberikan motivas belajar disela-sela proses pembelajaran, akan tetapi itu tergantung dengan mata pelajaran serta ustadz nya sendiri. Tidak sesering mungkin dalam penyampaian motivasi belajar.

\section{Supervisi guru}

Hampir semua guru membantu dan mengarahkan untuk bisa memahami sebuah materi pelajaran, akan tetapi ada juga guru yang dalam menerangkan terlalu cepat. Akibatnya ada beberapa mahasiswa yang belum paham secara optimal.

\section{Penilaian evaluasi}

Pada aspek penilaian ini para guru sudah memakai indikator kehadiran, tugas dan juga ulangan harian. Meskipun ada indikator lain yang lebih penting yaitu kecakapan siswa atau keterampilan dalam penggunaan bahasa Arab selama di lingkungan Mahad.

\section{Faktor belajar individu}

Dari faktor jasmaniah, para mahasiswa mahad Ali sudah menunjukkan fisik maupun keadaan badan yang mendukung untuk mengikuti proses belajar di Mahad. Sedangkan untuk faktor rohaniah kebanyakan mahasiswa mempunyai minat untuk belajar bahasa Arab, hanya saja dalam hal penyampaian salah ustadz yang terlalu cepat membuat pemahaman jadi kurang.

\section{Faktor dari lingkungan}

Aspek faktor sosial mahasiswa mahad Ali kebanyakan dapat dorongan belajar dari 
diri sendiri, karena keyakinan dalam diri untuk belajar bahasa Arab dan studi Islam. Sedangkan faktor non sosial mahasiswa mahad Ali dapat dikatakan memprioritaskan pekerjaan ataupun hal lain yang tidak bisa di tinggal dari kegiatan belajar di Mahad.

\section{Faktor strategi dan metode}

Aspek strategi dan metode adalah bagaimana cara para mahasiswa mempelajari materi baru yang di dapatkan. Rata-rata mahasiswa menanyakan kepada teman yang sudah lebih dulu paham akan materi yang di ajarkan, walaupun ada yang belajar mandiri lewat youtube.

Kecerdasan intelektual Mahasiswa menurut indikatornya mencakup baik ingatannya, cakap memecahkan masalah, cepat dalam mengamati dan mudah menarik kesimpulan.

\section{Baik ingatan}

Cara mahasiswa mahad Ali dalam mengingat materi jangka panjang adalah dengan mengulang kembali pelajaran, membaca ringkasan dari buku dan juga mengajarkan kepada teman yang belum paham. Untuk mengingat materi jangka pendek dengan mempraktekkan di aktivitas sehari-hari dan murojaah atau mempelajari kembali.

\section{Mudah menarik kesimpulan}

Indikator pertama menarik kesimpulan seluruh materi pelajaran, di sini cara mahasiswa mahad Ali dengan mendengarkan penjelasan guru, berlatih bersama teman dan juga mengerjakan tugas serta PR. Untuk menarik kesimpulan salah satu materi pelajaran dengan cara bertanya kepada teman yang lebih paham dan juga bertanya langsung kepada guru.

\section{Cepat dalam mengamati}

Mahasiswa mahad Ali mengamati materi pelajaran baru dengan cara melihat judul setiap buku panduan pelajaran dan bertanya kepada teman yang belum paham. Untuk mengamati penjelasan guru mahasiswa terkendala dalam bahasa Arab, karena dalam penyampaian guru menggunakan bahasa Arab dan ada juga yang sudah mengerti walaupun sedikit.

\section{Cakap memecahkan masalah}

Cara memecahkan masalah menurut aspek tujuan pembelajaran pada mahasiswa mahad Ali dengan cara membaca dan menulis setiap kosa kata yang baru serta membuka kamus dan bertanya kepada teman. Sedangkan untuk aspek mememcahkan masalah pembelajaran para mahasiswa rata-rata dengan bantuan teman para mahasiswa mahad Ali.

Motivasi belajar Mahasiswa dilihat dari indikatornya yaitu adanya jiwa penghargaan dalam belajar, adanya hasrat dan keinginan berhasil, adanya harapan dan cita-cita dan adanya dorongan dan kebutuhan belajar.

\section{Adanya dorongan dan kebutuhan belajar}

Dorongan para mahasiswa di mahad Ali untuk belajar bahasa Arab dan studi Islam adalah dari diri sendiri serta untuk memahami $\mathrm{Al}$ qur'an dan hadits. Adapun kebutuhan yang paling penting adalah bisa membaca kitab gundul serta menggapai cita-cita belajar di timur tengah.

\section{Adanya hasrat dan keinginan berhasil}

Tekad atau hasrat yang ingin dicapai para mahasiswa Mahad Ali adalah bisa membaca, menulis dan menterjemahkan serta berbicara bahasa Arab aktif. Kemudian memperdalam ilmu Islam dengan baik dan benar. Selanjutya aspek keinginan berhasil dari pada mahasiswa sendiri rata-rata adalah tetap melanjutkan studi nya walaupun misal ada yang tinggal kelas.

\section{Adanya harapan dan cita-cita}

Harapan dari pada mahasiswa Mahad Ali adalah bisa mengamalkan ilmu bahasa Arab meliputi membaca, menulis, menerangkan atau mengartikan ilmu studi Islam kepada masyarakat. Karena salah satu cara untuk menjaga ilmu yang sudah di dapat di Mahad. Sedangkan untuk cita-cita adalah lanjut kuliah ke luar negeri jurusan ilmu syar'i dan juga menjadi guru ataupun dosen. 


\section{Adanya jiwa penghargaan dalam belajar}

Para mahasiswa Mahad Ali mengatakan bahwa jiwa dalam belajar bahasa Arab adalah bagian dari memperdalam Al-Qur'an, karena bahasa arab adalah bahasa Al-Qur'an dan bahasa umat Islam. Sedangkan penghargaan diri dalam belajar adalah mempunyai kapasitas ilmu agama dan bahasa Arab secara khusus.

Selanjutnya poin terakhir dari pada penelitian ini adalah menggabungkan antara pengaruh proses belajar dengan kecerdasan intelektual dan motivasi belajar.

Proses belajar efektif di mahad Ali sudah efektif adalah bahwa dalam pembelajaran masih kurang dalam penggunaan bahasa Arab di lingkungan mahad sehari-hari. Hal itu akan lebih efektif apabila di rutinkan atau di wajibkan berbahasa di lingkungan mahad, karena dapat mendukung dalam hal memahami materi pelajaran. Sebagai bahan dan juga melatih kefasihan dalam berbahasa Arab.

Agar terciptanya proses belajar yang efektif di mahad Ali adalah bagaimana cara seorang ustadz atau guru membangun relasi antar mahasiswa. Agar menumbuhkan jiwa seorang penuntut ilmu yang baik. Serta menanamkan niat dan tujuan lebih dulu dari awal, supaya kedepannya tahu apa yang akan dikerjakan setelahnya. Kemudian cara atau metode dalam mengajarnya, kemudian dalam mengelola proses belajar yang baik sesuai yang di harapkan peserta didik dalam artian disini adalah mahasiswa itu sendiri.

Kesimpulannya, apakah proses belajar efektif di mahad Ali ada pengaruhnya terhadap kecerdasan intelektual dan motivasi belajar adalah bahwa dalam kegiatan pembelajarannya mahasiswa di tuntut untuk mahir dalam berbahasa Arab. Meskipun ada juga lulusan non-pondok yang agak terkendala dengan materi pelajarannya, itu tidaklah menjadi masalah yang rumit. Kemudian hal yang membuat berpengaruh dalam proses belajar efektif adalah membangkitkan motivasi untuk selalu belajar ilmu syar'i

\section{KESIMPULAN}

Proses belajar efektif Mahasiswa Mahad Ali. Dalam aspek presensi belajar dan melakasanakan tugas sudah dapat dikatakan dengan baik, meskipun dengan bantuan teman akan lebih dapat di mengerti bersama-sama. Kemudian untuk kemampuan dalam belajar mahasiswa mengulang materi dan latihan soal. Suasana belajar yang positif lebih sering berdiskusi kumpul agar dapat belajar bersama.

Selanjutnya adalah job dexcription guru dalam proses belajar yaitu perencananaan instruksional mengacu kepada kurikulum yang berlaku di Mahad Ali. Kemudian organisasi belajar menggunakan buku Silsilah Lughotul Arabiyyah sesuai wadah kurikulum. Guru maupun Ustadz rata-rata sudah bisa memberikan motivasi belajar, pemahaman materi maupun membantu dalam belajar. Untuk penilain di lihat dari kehadiran, tugas, dan juga ulangan harian.

Faktor yang mendukung proses belajar dari individu adalah adanya minat dalam belajar bahasa Arab. Kemudian faktor dari lingkungan adalah dari dorongan diri sendiri karena yakin dari diri sendiri, serta faktor dari strategi dan metode mahasiswa menanyakan kepada teman yang sudah lebih dulu paham materi yang di ajarkan.

Kecerdasan Intelektual Mahasiswa Mahad Ali. Pada indikator ingatan yang baik adalah dengan cara mengulan kembali pelajaran, membaca ringkasan materi dari buku dan mengajarkan kepada teman melalui praktek harian. Kemudian cara menarik kesimpulan dengan cara mendengarkan penjelasan guru, berlatih bersama teman dan bertanya kepada guru maupun teman. Selanjutnya untuk cara cepat dalam mengamati dengan mencatat setiap materi yang di sampaikan dan juga mengamati penjelasan dari guru. Serta cakap dalam memecahkan masalah di sini dengan cara membaca dan menulis setiap kosa kata baru untuk kemudian di gunakan dalam proses belajar dan juga membuka kamus.

Motivasi Belajar pada Mahasiswa Mahad Ali. Pertama aspek adanya dorongan dari dalam 
diri untuk mempelajari bahasa Arab dan studi Islam, untuk memahami Al-qur'an dan hadits. Untuk kebutuhan belajar adalah bisa membaca kitab tanpa harakat (gundul) serta menggapai impian belajar di timur tengah. Selanjutnya hasrat atau tekad dalam belajar adalah aktif dalam berbahasa arab (membaca, mendengarkan, menulis, dan menterjemahkan). Kemudian adanya harapan untuk menjaga ilmu yang sudah di pelajari dan menjadi dosen maupun guru. Jiwa penghargaan terbesar dalam belajar adalah kapasitas ilmu syar'i dan bahasa Arab secara khusus dan mendalam, dan karena bahasa Arab adalah bagian dari memperdalam Al-qur'an.

Pengaruh Proses Belajar Efektif dengan Kecerdasan Intelektual dan Motivasi Belajar Mahasiswa Mahad Ali. Apakah proses belajar efektif di mahad Ali ada pengaruhnya terhadap kecerdasan intelektual dan motivasi belajar adalah bahwa dalam kegiatan pembelajarannya mahasiswa di tuntut untuk mahir dalam berbahasa Arab. Meskipun ada juga lulusan non-pondok yang agak terkendala dengan materi pelajarannya, itu tidaklah menjadi masalah yang rumit. Kemudian hal yang membuat berpengaruh dalam proses belajar efektif adalah membangkitkan motivasi untuk selalu belajar ilmu syarei.

\section{DAFTAR PUSTAKA}

Ahmadi, Abu dan Joko Prasetya. 1997. "Strategi Belajar Mengajar". Bandung: Pustaka Setia.

Kurniawan, Deni. 2014."Pembelajaran Terpadu Tematik (Teori, Praktik, dan Penilaian)". Bandung: Alfabeta.

Makmun, A.S. 2004.” Psikologi kependidikan”. Bandung: Rosdakarya.

Moleong, Lexy. 2014."Metodologi Penelitian Kualitatif”. Bandung: Remaja Rosdakarya.

Mujib, A., dan Mudzakir, Y. 2000. "Nuansa Nuansa Psikologi Islami”. Raja Grafindo Persada. Jakarta.

Uno, Hamzah B. 2007. "Teori Motivasi dan Pengukurannya”. Jakarta: Bumi Aksara.

Rohmawati, Afifatu. 2015."Efektivitas Pembelajaran”. Jurnal Pendidikan Usia Dini. Vol. 9 Edisi 1, April 2015.

Sukmadinata, Nana Syaodih. 2003. "Landasan Psikologi Proses Pendidikan". Bandung: PT Remaja Rosdakarya.

Syaodih Sukmadinata, Nana. 2014. "Metode Penelitian Pendidikan". Bandung: PT Remaja Rosdakarya.

Trianto. 2009. "Mendesain Model Pembelajaran Inovatif-Progresif". Jakarta: Kencana. 